\title{
Pemanfaatan Event sebagai Upaya Public Relations dalam Membangun Reputasi Perusahaan (Studi pada PT. XYZ sebagai pendukung kegiatan

\author{
Asian Games 2018)
}

\author{
Feberi Jenty, Yugih Setyanto S.Sos.,M.Si. \\ Feberi.915150054@stu.untar.ac.id,yugihs@fikom.untar.ac.id \\ Fakultas Ilmu Komunikasi Universitas Tarumanagara
}

\begin{abstract}
:
The Role of Public Relations is very important today for a company to build a reputation. In building the reputation of a company of course there are the programs and activities of Public Relations. One of the activities is the Public Relations event. Asian Games 2018 is one of the biggest events and attended by 45 countries, which this year was held in Indonesia. Many companies that become big event sponsorship in this, one of which is PT $X Y Z$ as the official mobile partner on this occasion, which was held August 18, 2018 until September 2, 2018. A huge honor for PT. XYZ can be mobile partner in a big event, especially in building the company's reputation with the $5 G$ Experience Center at the Bung Karno (GBK). Reputation PT. XYZ when the 2018 Asian Games can be measured through PR Value which is demonstrated by the available data. This research method using descriptive qualitative case study. The results of this study that the event can build a reputation company PT. XYZ with the data obtained from the PR Value and also their $5 G$ Experience Center which diquote by President Joko Widodo.
\end{abstract}

Keyword : Public Relations, Reputation

\begin{abstract}
Abstrak :
Peran Public Relations sangat penting saat ini bagi sebuah perusahaan dalam membangun reputasi. Dalam membangun reputasi sebuah perusahan tentunya ada program-program maupun aktivitas Public Relations. Salah satu aktivitas Public Relations yaitu event. Asian Games 2018 merupakan salah satu event terbesar dan dihadiri oleh 45 negara, yang pada tahun ini diselenggarakan di Indonesia. Banyak sekali perusahaan yang menjadi sponsorship dalam event besar ini, salah satunya adalah PT. XYZ yang sebagai official mobile partner dalam kesempatan ini yang diadakan 18 Agustus 2018 sampai dengan 2 September 2018. Sebuah kehormatan besar bagi PT. XYZ dapat menjadi mobile partner dalam perhelatan yang besar terutama dalam membangun reputasi perusahaan dengan adanya $5 \mathrm{G}$ Experience Center di Gelora Bung Karno (GBK). Reputasi PT. XYZ saat Asian Games 2018 dapat diukur melalui PR Value yang dibuktikannya dengan data yang ada. Metode penelitian ini menggunakan kualitatif deskriptif dengan studi kasus. Adapun dari hasil penelitian ini bahwa event dapat membangun reputasi perusahan PT. XYZ dengan data yang didapat dari PR Value dan juga adanya 5G Experience Center yang diquote oleh Presiden Joko Widodo.
\end{abstract}

Kata Kunci : Public Relations, Reputasi 


\section{Pendahuluan}

Saat ini jaman menuntut serba instan dan praktis, baik dalam sistem kerja maupun halnya dalam berkomunikasi. Komunikasi yang begitu cepat dengan teknologi yang begitu canggih sangatlah diiming-imingi oleh masyarakat jaman sekarang. Salah satu alat komunikasi yang canggih sekalipun saat ini, memerlukan Internet Service Provider (ISP). ISP adalah perusahaan yang menyediakan berbagai layanan yang menyangkut internet.

Salah satu perusahaan yang penyedia ISP dan telekomunikasi seluler di Indonesia yaitu PT. Telekomunikasi Seluler (XYZ) adalah sebuah perusahaan yang bergerak dibidang operator telekomunikasi seluler khususnya di Indonesia dan perusahaan ini juga mengklaim sebagai perusahaan telekomunikasi terbesar di Indonesia dengan menjadi operator seluler ketujuh di dunia yang mempunyai lebih dari 143 juta pelanggan dalam satu negara pada tahun 2015-2016. Saat ini pelanggan XYZ tercatat 178 juta yang tersebar di seluruh Indonesia, termasuk juga di daerah terpencil dan pulau terluar bahkan daerah perbatasan negara. XYZ memiliki jaringan yang telah mencakup 288 jaringan roaming internasional di 155 negara pada akhir tahun 2007 dan menggelar lebih dari 146 Base Transceiver Stasion (BTS) yaitu sebuah infrastruktur telekomunikasi yang memfasilitasi komunikasi nirkabel antara piranti komunikasi dan jaringan operator. Perusahaan yang besar tidak lepas dari peran seorang Public Relations yang dapat membangun hubungan yang baik antara pihak eksternal dan internal perusahaan yang dapat membangun reputasi sebuah perusahan.

Saat Asian Games, XYZ terpilih menjadi Official Mobile Partner. XYZ mensupport dengan membuka 100 mobile GraPARI yang didalamnya melayani segala bentuk transaksi pembelian pulsa, paket data, dan penukaran poin XYZ dengan merchandise yang tersedia di pavilion tersebut. Ada beberapa produk yang mereka tawarkan untuk memeriahkan Asian Games 2018 ini. XYZ juga membuka booth yang memamerkan 5G Experience Center yang di dalamnya pengunjung dapat langsung mencoba bagimana keunggulan dari 5G, dan memamerkan Cycling Everywhere, Football 2022, Beat the Robot, Future Driving, dan Autonomous Electric Vehicle. Hal ini yang merupakan salah satu cara XYZ membangun reputasi perusahaan mereka kepada masyarakat.

Sementara itu, Menurut John Dalton dalam bukunya Managing Corporate Reputation yang dikutip dalam jurnal Sutanza, Bangkit dan Widiyanto, Ibnu (2013). Reputasi adalah semua total penilaian dari atribut stakeholder pada perusahaan, berdasarkan persepsi dan interprestasi pada citra perusahaan yang dikomunikasikan secara terus-menerus. Berdasarkan pengertian tersebut bahwa reputasi harus diperjuangkan sedangkan citra dapat dibentuk, namun reputasi hanya bisa diperoleh dengan membangunnya. Maka dari itu, penulis melakukan penelitian mengenai "Peran Public Relations PT. XYZ dalam Membangun Reputasi Melalui Asian Games 2018".

Dalam penelitian ini, peneliti menggunakan beberapa teori yaitu: Komunikasi: Komunikasi merupakan hal yang mendasar dari kehidupan sosial seorang manusia yang menjadi kebutuhan sangat penting. Hal ini dikarenakan manusia merupakan makhluk sosial yang membutuhkan transaksi dengan sesamanya. Baik itu untuk menyampaikan informasi, perasaan, pikiran, pendapat ataupun sikapnya. Jadi dapat disimpulkan bahwa komunikasi adalah proses sosial yang berisikan pertukaran pesan antara komunikan I dan komunikan II yang terjadi secara berkesinambungan melalui 
Feberi Jenty, Yugih Setyanto S.Sos.,M.Si.: Pemanfaatan Event sebagai Upaya Public Relations dalam Membangun Reputasi Perusahaan (Studi pada PT. XYZ sebagai pendukung kegiatan

Asian Games 2018)

media yang bertujuan memberikan makna pesan untuk membentuk perilaku manusia dan adat kebiasaan.

Public Relations dan Hubungan Masyarakat (Humas): Sehingga dapat disimpulkan bahwa public relations adalah praktisi yang dapat membangun hubungan baik dengan publiknya yaitu internal dan eksternal dari perusahaan serta dapat mengelola citra dan reputasi perusahaan dengan menggunakan fungsi-fungsi komunikasi dalam mencapai tujuan perusahaan terhadap khalayaknya.

Peran Public Relations: Peran Public Relations (PR) atau Hubungan masyarakat di dalam sebuah perusahaan dibagi menjadi empat kategori utama, menurut Scott M. Cutlip et al, dalam bukunya Effective Public Relations (2009 : 45), yaitu:

\section{Expert prescriber}

Seorang expert prescriber adalah seorang yang menjalankan peran seperti seorang konsultan. Ia adalah seorang yang dapat dipercaya untuk memecahkan masalah yang sedang dihadapi. Hubungan dengan klien seperti hubungan antara dokter dengan pasien dimana pasien hanya pasif mendapat masukan dan nasehat. Praktisi yang berperan sebagai expert prescriber akan mengidentifikasikan masalah, mengembangkan rancangan program, dan memegang tanggung jawab penuh dalam implementasi program yang telah dirancangnya itu. Kegagalan dan keberhasilan suatu program sepenuhnya merupakan tanggung jawab expert prescriber ini.

2. Communication fascilitator

Peran ini menempatkan praktisi public relations sebagai seorang pendengar yang baik dan penyedia informasi. Fungsi praktis adalah sebagai penghubung, interpreter, dan mediator antara organisasi dengan publiknya. Peran ini mencoba memelihara komunikasi dua arah dan memfasilitasi pertukaran informasi dengan menciptakan dan memelihara saluran-saluran media komunikasi yang diperlukan. Peran ini ada berdasarkan asumsi bahwa komunikasi dua arah yang efektif akan meningkatkan kualitas keputusan organisasi dan publik mengenai antara lain kebijakan, prosedur, tindakan dan hubungan yang saling menguntungkan.

3. Problem solving fascilitator

Praktisi yang menjalankan peran ini bekerja besama-sama dengan para manajer untuk memecahkan masalah. Praktisi public relations menjadi bagian dari tim strategis. Hal ini bisa terjadi bila praktisi public relations mampu mempergunakan dan menunjukkan keterampilan dan nilai dirinya dalam membantu manajemen dalam memecahkan masalah.

4. Communication technician

Praktisi public relations dikatakan berperan sebagai communication technician bila pekerjaannya sehari-hari hanyalah menerima perintah dari atasan. Umumnya, pekerjaan yang dilakukan antara seperti menulis, mengedit, membuat press release, website, annual report, mempersiapkan pidato dan pekerjaan teknis lainnya.

Reputasi: Reputasi dapat dibangun berpuluh-puluh tahun, tapi dapat runtuh dan luluh lantak hanya dalam hitungan detik. Begitu adagium klasik yang kerap terdengar bila membahas ikhwal reputasi. Baik reputasi individu, organisasi, hingaa reputasi sebuah korporasi. Semua sama prosesnya, butuh waktu, upaya, kerja keras, dan menghadirkan pengalaman nyata yang penuh dengan kisah kejujuran. Inti dari reputasi memang terletak pada kejujuran dan kepercayaan. Sehingga dapat disimpulkan bahwa reputasi dibangun bukan sehari, seminggu, bahkan sebulan 
melainkan berpuluh-puluh tahun untuk mendapatkan penilaian yang positif dari publik mengenai organisasi atau korporat yang dicapai melalui kejujuran dan kepercayaan.

Faktor Pembentuk Reputasi: Menurut Elizabeth Goenawan Ananto (2016), pendiri EGA briefings, dalam buku reputasi yang berkarakter (2017 : 99) image perusahaan itu hanya bagian kecil dari proses pembentukan reputasi. Bagaimana kesan publik kala membeli produk atau jasa memberi sumbangsih penting bagi reputasi perusahaan. Bahkan, sikap dan perilaku karyawan perusahan juga berperan dalam menentukan kuat atau lemahnya reputasi perusahaan.

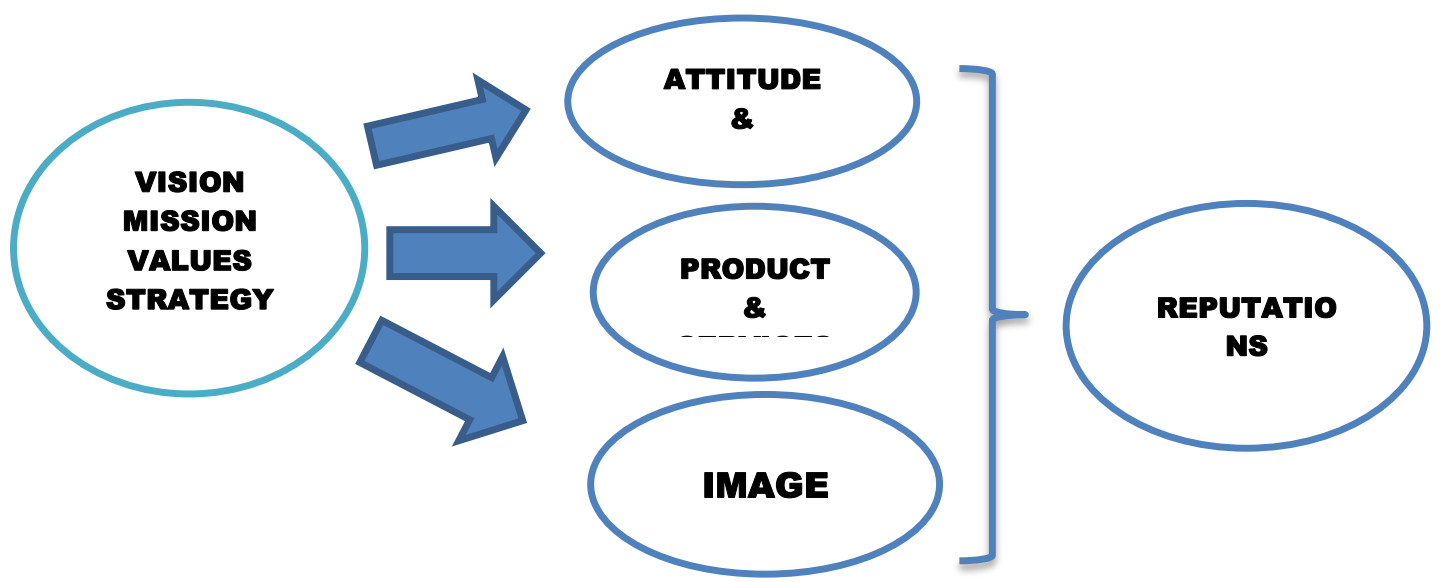

Event Sponsorship

Dalam sebuah event, tentunya ada sponsorship dan partnership, Menurut Suwatno (2017: 94), sponsorship adalah pertukaraan antara sponsor (pemberi sponsor) dan sponsee (penerima sponsor) yaitu sponsor memperoleh hak untuk mengasosiasikan dirinya dengan aktivitas sponsorship sementara sponsee menerima bayaran (fee) dari sponsor tersebut. Fungsi dari sponsorship yaitu mengangkat (leverage) nilai suatu brand. Perusahaan menggunakan event sebagai:

1. Untuk meningkatkan brand awareness

2. Untuk mengasosiasikan brand perusahaan dengan aktivitas masyarakat

3. Untuk menyasar target pasarnya.

Sehingga dapat disimpulkan, bahwa peran seorang public relations memiliki ruang lingkup yang salah satunya sebagai peneyelenggara events melalui aktivitas yang ada, salah satunya adalah event management, exhibitions dapat membangun komunikasi eksternal sebuah perusahaan dengan menanamkan citra yang baik mengenai product, service dan social responsibility kepada masyarakat dapat membangun reputasi sebuah perusahaan. Bukan dengan menyelengarakan events saja melainkan dengan ikut berpartisipasi dengan acara kenergaraan guna membangun government relations yang baik dengan menjadi sponsorship, yang dapat meningkatkan brand awareness dan menaikan brand image dimata masyarakat.

\section{Metode Penelitian}

Penelitian yang dilakukan oleh penulis bertujuan mengetahui tentang peran public relations PT. XYZ dalam membangun reputasi melalui Asian Games 2018. Pada penelitian ini penulis menggunakan metode penelitian kualitatif secara deskriptif. 
Feberi Jenty, Yugih Setyanto S.Sos.,M.Si.: Pemanfaatan Event sebagai Upaya Public Relations dalam Membangun Reputasi Perusahaan (Studi pada PT. XYZ sebagai pendukung kegiatan

Asian Games 2018)

Melalui teori diatas dapat dilihat bahwa penelitian kualitatif adalah penelitian yang bersifat deskriptif dan analisis menggunakan pengumpulan data untuk menjelaskan fenomena yang diteliti. Peneliti menggunakan metode tersebut dikarenakan sesuai dengan perumusan masalah penulis untuk mengetahui peran public relations PT. XYZ dalam membangun reputasi melalui Asia Games 2018. Dalam penelitian ini yang menjadi subjek penelitian adalah PT. XYZ dan objek penelitian adalah upaya public relations melalui peran public relations. Serta, Dalam penelitian ini peneliti menggunakan wawancara terstruktur agar peneliti dapat memperoleh data dengan pasti dan lancar. Peneliti akan melakukan wawancara dengan informan yang memenuhi kriteria terkait dengan kajian penelitian.

Penelitian ini menggunakan observasi non-partisipan dengan observasi terstruktur. Dalam penelitian ini, peneliti mengamati peran public relations PT. XYZ dalam membangun reputasi melalui Asian Games 2018. Peneliti menggunakan dokumentasi yang berkaitan dengan kajian penelitian untuk memperkuat dan memperkaya penelitian peneliti. Penulis menggunakan studi kepustakaan seperti buku-buku maupun jurnal penelitian yang berkaitan dengan masalah dan metode penelitian sebagai sumber data dan landasan teori. Penulis memanfaatkan studi kepustakaan untuk memperkuat penelitian. Peneliti melakukan teknik pengolahan data dengan pengumpulan data terlebih dahulu, kemudian reduksi data yaitu yang terkait dengan peran public relations PT. XYZ yang mana dapat membangun reputasi dengan melalui Asian Games 2018 untuk dapat ditarik kesimpulannya.

Lalu peneliti melakukan penyajian data, yaitu mengambil data secara deskriptif agar data lebih mudah dipahami mengenai peran public relations PT. XYZ dalam membangun reputasi melalui Asian Games 2018. Serta langkah terakhir melakukan kesimpulan dan verfikasi yaitu menyimpulkan dari hasil wawancara dengan narasumber sebagai awal untuk data tersebut diolah dan dianalisis untuk mendapatkan kesimpulan dan verifikasi. Peneliti juga melakukan teknik keabsahan data dengan triangulasi yaitu mengkaitkan penelitian terdahulu, teori dan hasil wawancara

Hasil Penelitian: Jika Menurut XYZ saat ini seorang praktisi PR adalah strategis yaitu seseorang yang dapat dapat berhubungan dengan semua stakeholder untuk bergerak bersama oleh satu tujuan. Karena PR saat ini bukan sebagai tukang make up yang jelek jadi bagus, atau jadi spinner. PR dapat mengumpulkan berbagai macam pihak, dan berbagai situasi dan dapat diarahkan dengan satu tujuan.

Antara teori dan temuan yang peneliti dapatkan di lapangan mengenai PR, bahwa PR yang bekerjasama dengan membangun hubungan yang baik kepada publiknya, publiknya sendiri yaitu stakeholdernya. Contoh halnya stakeholder PT. XYZ yaitu pihak eksternal dan internal, pihak eksternal XYZ yaitu pemerintah, investor, pelanggan dan room back sound medial. Jika pihak internalnya sendiri yaitu karyawan, internal advokat dan para kelurga karyawan. PR diera digital dituntut cepat dan harus menyesuaikan diri dengan program mereka di era ini.

Keikutsertaan XYZ dalam Asian Games 2018 sebagai official mobile partner dari tanggal 18 Agustus sampai 2 September 2018 yang diselenggarakan di Jakarta dan Palembang. Dalam event yang begitu bergengsi tersebut, XYZ tidak hanya sebagai official mobile partner yang menyediakan 100 mobile GraPARI yang diharapkan dapat melayani pelanggan selama Asian Games 2018, lalu menyediakan total stock produk 41.000 kartu perdana SimPATI dengan adanya 20.000 paket untuk relawan Asian Games 2018 dan 21.000 paket untuk kontigen Asian Games 2018 dari masing-masing negara yang terdiri dari atlet, ofisial, dan jurnalis. Adapun Dukungan 
Network Infrastructure dilakukan dalam rangka mengamankan 175 POI (point of interests/ titik prioritas utama) yang berada di 3 lokasi yaitu 51 titik arena pertandingan yang diantaranya berada di Stadion Utama Gelora Bung Karno (GBK) Jakarta, Stadion Si Jalak Harupat Bandung, dan Stadion Jakabaring di Palembang. Lalu 59 titik diluar arena pertandingan untuk pengamanan jaringan yaitu media center, broadcast center, serta beberapa tempat penginapan atlet dan jurnalis. Serta, 65 titik lokasi penyangga pertandingan yang berada di public area seperti bandara dan pusat perbelanjaan.

Dalam Asian Games 2018, XYZ memperkenalkan kepada public mengenai 5G dengan adanya 5G Experience Center di Gelora Bung Karno (GBK) Jakarta. Adanya 5G Experience Center ini, XYZ berharap dapat memberikan edukasi tentang 5G dengan ilustrasi dan gambaran kepada masyarakat Indonesia. Dalam 5G Experience ini ada beberapa gambaran mengenai teknologi ini seperti Cycling Everywhere, Football 2022, Beat the Robot, Future Driving dan Autonomous Electric Vehicle. Selain hal itu juga, XYZ ikutserta dan mendukung kegiatan pawai obor yang berada di lima kota yaitu Solo (19/7), Mataram (25/7), Tanjung Bira (28/7), Bandar Lampung (8/8) serta Jakarta (18/8).

XYZ sendiri dalam menyatakan sukses tidaknya dalam Asian Games 2018 sebagai official mobile partner, melakukan perhitungan dengan PR Value. Berdasarkan data yang diamati oleh peneliti, dalam publikasi XYZ mencapai 41,3 miliyar, ada 97 discoverage, 34 miliyar discoverage online, 47 online dan 27 offline. Serta saat XYZ membuka booth $5 G$ Experience Center hal ini dibuktikan dengan dihadiri oleh 8 menteri serta dikutip juga oleh Jokowi dalam World Economy Class.

Dalam event tentunya ada hambatannya, menurut Dr. Dra. Lidya Wati Evelina, M.M, adalah komitmen orang-orang yang dalam menyelenggarakannya event tersebut. Karena event merupakan adalah salah satu tools PR. Jika pemasaran lebih keranah marketing. Jika event di konsep marketing lebih kepada penjualan, sedangkan dalam konsep PR event tidak menjual hanya sebagai memperkenalkan produk dan cara penggunaannya atau campaign program. Seperti halnya event pameran berarti memerkan dan di dalamnya tidak boleh sama sekali menjual.

Contohnya Jakarta Fair, sebelumny hanya sekadar memarkan produk baru. Tetapi sekarang Jakarta Fair dijadikan tempat berjualan. Seperti jika ada pameran buku, kita hanya boleh memesan buku, dan tidak secara langsung mendapatkan barangnya. Karena eventnya pameran yang bersifat memamerkan.

Adapun penelitian yang sama dengan hal ini bahwa melalui event dapat membangun reputasi yaitu melalui penelitian MONIK, NOVI and Wati Evelina, Lidya (2012) Strategi Promosi Event Konser Jesus Rock - Disciples Untuk Membangun Reputasi PT. Inspirasi Utama (Insight Unlimited) Periode April 2012. Undergraduate thesis, BINUS.

Dalam penelitiannya, bahwa perusahaan telah melakukan perannya dengan baik dengan strategi promosi yang dilakukan untuk event konser Jesus RockDisciples yang dapat membangun reputasinya di masyarakat dengan baik. Hal ini senada denga PT XYZ yang juga menjalankan perannya sebagai public relations yang dapat berbaur di masyarakat dan dapat membangun reputasinya.

\section{Simpulan}

Dalam penelitian yang dilakukan oleh peneliti ada beberapa kesimpulan yang didapat, seperti di bawah ini : 
Feberi Jenty, Yugih Setyanto S.Sos.,M.Si.: Pemanfaatan Event sebagai Upaya Public Relations dalam Membangun Reputasi Perusahaan (Studi pada PT. XYZ sebagai pendukung kegiatan

Asian Games 2018)

1. Public Relations PT. XYZ melihat PR itu strategis yaitu bukan sebagai tukang make up yang jelek jadi bagus, atau jadi spinner. PR dapat mengumpulkan berbagai macam pihak, dan berbagai situasi dan dapat diarahkan dengan satu tujuan.

2. Public Relations PT.XYZ menjalankan perannya sebagai seorang praktisi PR yaitu dalam menerapkan keempat peran PR menurut Scott M. Cutlip

3. Aktivitas PR yang dilakukan PT. XYZ berjalan dengan semestinya dengan fungsi-fungsinya dalam penerapannya dimasyarakat terutama event yang salah satu aktivitas PR dapat membangun reputasi perusahaan.

4. Dalam membangun reputasi, XYZ memiliki hambatan namun, hal tersebut dibuktikannya dengan tetap membangun reputasinya sebagai official mobile partner dalam Asian Games 2018 yang di mata masyarakat sendiri melihat XYZ merupakan salah satu pelopor teknologi komunikasi di Indonesia.

\section{Ucapan Terima Kasih}

Ucapan terimakasih ditunjukan kepada Tuhan Yang Maha Esa, Orang tua dan narasumber yaitu Ojid selaku pihak XYZ dan Dr. Dra. Lidya Wati Evelina, M.M selaku ahli komunikasi serta kepada teman-teman yang telah memberikan dukungan secara spiritual dan materil.

\section{Daftar Pustaka}

Moh. Nazir. (2011). Metode Penelitian. Bogor : Penerbit Ghalia Indonesia.

Rosady Ruslan. (2017). Metode Penelitian : Public Relations dan Komunikasi. PT. Raja Grafindo Persada : Jakarta

Ahmad Beni. (2016). Komunikasi Antarbudaya. Bandung : CV. Pustaka Setia

Nova,Firsan. (2014). PR WAR..Jakarta. Grasindo

Scott M. Cutlip; allen H. Center; Glen M. Broom. (2009). Effective Public Relations .Kencana Prenada Media Group.

Tench dan Yeomans. (2009). Exploring Public Relations. Prentice Hall.

Mochamad, Dyah dan Frizki . (2017). Reputasi yang Berkarakter. Jakarta : PT. Media Piar Indonesia

Suwanto. (2017). Komunikasi Pemasaran Kontekstual. Bandung : Simbiosa Rekatama Media.

Moleong Lexy. (2009). Metode Penelitian Kualitatif. Bandung: PT. Remaja Rosdakarya

Utanza, Bangkit and Widiyanto, Ibnu (2013) Analisis Pengaruh Brand Reputation, Brand Predictability, Brand Competence dan Brand Liking Terhadap Brand Loyalty Kendaraan Niaga Merek Mitsubishi (Studi Pada Pemilik Kendaraan Niaga Mitsubishi di Semarang). Undergraduate thesis, Fakultas Ekonomika dan Bisnis.

Monik, Novi and Wati Evelina, Lidya (2012). Strategi Promosi Event Konser Jesus Rock - Disciples Untuk Membangun Reputasi PT. Inspirasi Utama (Insight Unlimited) Periode April 2012. Undergraduate thesis, BINUS.

Lena Satlita. (2011). Media Public Relations. http:staff.uny.ac.id/dosen/lenasatlitadra-msi/PR-Minggu-08.pdf. 